
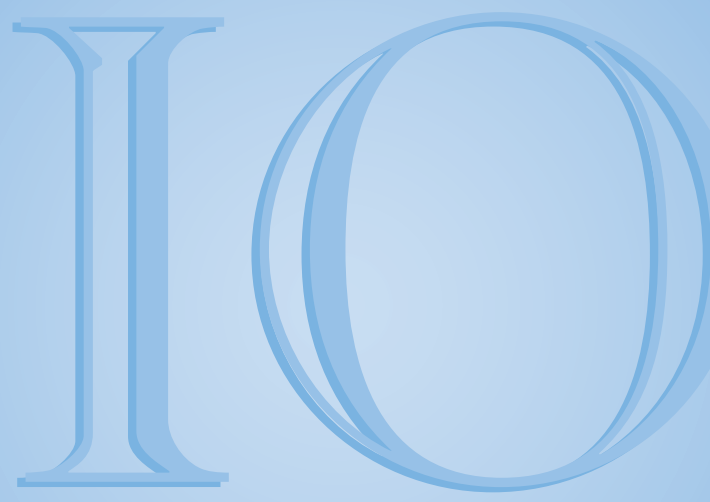

Erik Ringmar

Performing International Systems: Two East-Asian Alternatives to the Westphalian Order

Teri L. Caraway, Stephanie J. Rickard, and Mark S. Anner International Negotiations and Domestic Politics: The Case of IMF Labor Market Conditionality

Jarrod Hayes

Securitization, Social Identity, and Democratic Security:

Nixon, India, and the Ties That Bind

Sarah M. Brooks and Marcus J. Kurtz

Paths to Financial Policy Diffusion:

Statist Legacies in Latin America's Globalization

\title{
Research Notes
}

David B. Carter

A Blessing or a Curse? State Support for Terrorist Groups

\section{Michaela Mattes}

Democratic Reliability, Precommitment of Successor Governments, and the Choice of Alliance Commitment 


\section{International Organization}

Edited at The Munk School of Global Affairs,

University of Toronto

Published quarterly by Cambridge University Press Founded in 1947 by the World Peace Foundation

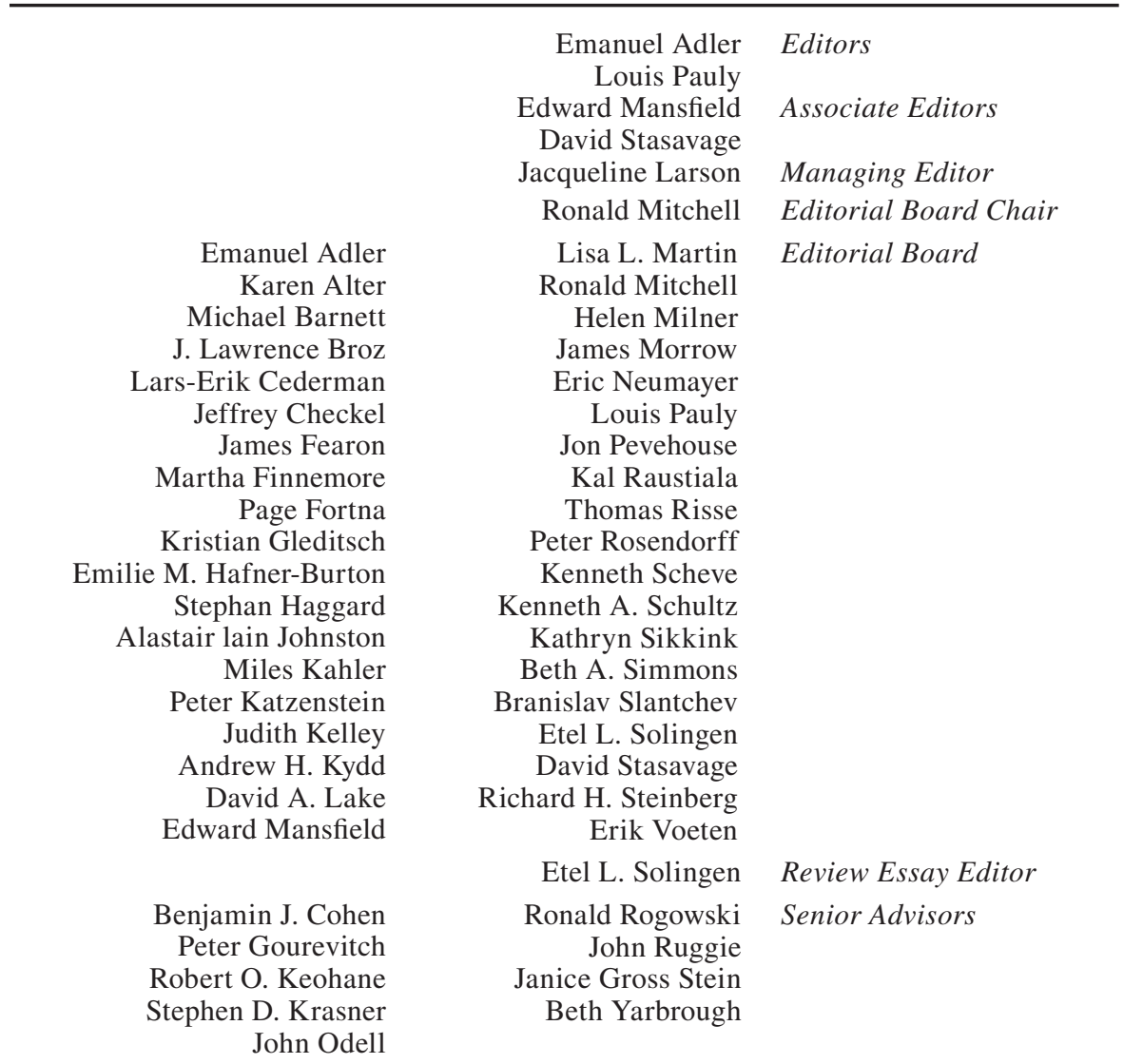

INTERNATIONAL ORGANIZATION invites the submission of original manuscripts on all aspects of world politics and international political economy. Authors should follow the guidelines published annually in the Winter issue. Guidelines also may be found on the World Wide Web at http://journals.cambridge.org.

Address for submissions: http://io.edmgr.com

For all other inquiries:

International Organization

The Munk School of Global Affairs, University of Toronto

1 Devonshire Place, Toronto, Ontario M5S 3K7, Canada

Statements and opinions expressed in International Organization are the responsibility of the authors alone and do not imply the endorsement of the Board of Editors, the Board of Trustees of the World Peace Foundation, the University of California, Cambridge University Press, or The Munk School of Global Affairs at the University of Toronto.

For abstracting listing and price information, please refer to the back of this issue. 


\section{International Organization}

Volume 66, Number 1, Winter 2012

\section{Articles}

Performing International Systems: Two East-Asian Alternatives to the Westphalian Order Erik Ringmar

International Negotiations and Domestic Politics: The Case of

IMF Labor Market Conditionality Teri L. Caraway,

Stephanie J. Rickard, and Mark S. Anner

Securitization, Social Identity, and Democratic Security:

Nixon, India, and the Ties That Bind Jarrod Hayes

Paths to Financial Policy Diffusion: Statist Legacies in Latin

\section{Research Notes}

A Blessing or a Curse? State Support for Terrorist Groups David B. Carter

Democratic Reliability, Precommitment of Successor Governments, and the Choice of Alliance Commitment Michaela Mattes 